\title{
The Flow and Ebb of Democracy's Third Wave
}

\section{L arry D iamond (U SA )}

$\mathrm{W}$

ith the sudden explosion of movements for democratic change across the Arab world at the beginning of 2011, many scholars and advocates of democracy began to speak excitedly of a "fourth wave" of democratic expansion. But within a few months, it became apparent that the revolutions in Tunisia and Egypt would not be repeated so easily elsewhere in the Arab world; that democracy remained a highly uncertain destination in each of these countries, particularly Egypt, in the near term; and that Arab autocracies were falling back on proven mixes of repression, cooptation, and limited or illusory "reform" in order to hang on. The fall in 2011 of three seemingly unassailable Arab autocrats-Zine Ben Ali, Hosni Mubarak, and Muammar Qaddhaffi - and the serious challenges to authoritarian rule in Yemen, Bahrain, and Syria, as well as the lesser but gathering opposition pressure in such other countries as Morocco and Jordan, are undeniable signs of the continued salience and attraction of the democratic ideal. Over time, they are likely to lead to at least some new democracies in the Arab world. But this prospect of a new burst of democratic change raises a more global question: What has become of the third wave of democracy? And what shapes the successes and failures of democracy?

The period of global politics since 1974, which Samuel P. Huntington labeled the "third wave" of global democratization, has seen the most sweeping transformation in the way that states are governed in the history of human civilization. During this period, democracy (meaning a political system in which people can choose and replace their leaders in regular, free, fair, and meaningful elections) has gone from being a preserve of the West and a few odd developing countries to a truly global phenomenon, the most common form of government in the world and the type of political system that the majority of human beings on earth live in. The percentage of states that are democracies increased from just slightly more than a quarter in 1973 to a third in 1980, about half in 1992, and then 60 percent in the year 2000. The expansion of democracy reached its high water mark in 2006, with 121 democracies, nearly 63 percent of all states. During this period democracy became the only broadly legitimate form of government in the world, the predominant form of government in several regions of the world, and a viable option in every region of the world except the Middle East. Among major cultural zones, only the Arab world lacked a single democracy. 
Latin America has gone from a region of scarce or chronically unstable democracy before the third wave to one where democracy is the predominant and expected form of government. There has been some worrisome erosion and stagnation. But for the first time ever, democracy has deepened and become consolidated in Latin America's largest country, Brazil, which less than two decades ago looked like it was mired in dysfunctional political institutions and recurrent economic crisis. And Chile has become one of the most liberal and durable democracies in what used to be called the "developing world," and an economic success story.

The fate of democracy totters some as one moves north from Latin America's Southern Cone. Since winning the presidential election in 1999, Venezuela's populist president, Hugo Chavez - who twice tried to seize power earlier in military coups - has gradually suffocated political pluralism and destroyed the independence and integrity of democratic institutions to the point where Venezuela ceased to be a democracy a number of years ago. To some extent, leftwing populist presidents in Bolivia and Ecuador, and more recently Nicaragua with the return to power of the Sandinista leader, Daniel Ortega, have done the same thing, mobilizing economic and social resentments to challenge democratic constitutional norms and restraints. It is an open question whether any of these three countries can still be called a democracy. But none of these leaders has succeeded in squelching the democratic process to the extent that Chavez has done and Chavez himself is under growing pressure of popular protest against his excesses. If democracy has become more stressed and unsettled in Central America and Mexico because of intensifying criminal violence due to the drug trade, at least there is no alternative to democracy being put forward. In Latin America, only Cuba rejects the model of electoral democracy altogether, and increasingly the society is deeply at odds with its regime there.

With the end of the Cold War and then the expansion of the European Union, Europe has become whole and democratic as never before in its long history of bloody conflict. All ten of the Central and East European countries that were admitted to the European Union between 2004 and 2007 have become consolidated and for the most part liberal democracies, though corruption and a weak rule of law remain serious challenges in a few countries, particularly Romania and Bulgaria. The completion of this vision of a Europe united by democratic values and institutions and by economic and social integration still confronts many challenges. The most urgent and profound one is the growing fiscal disarray of the Euro Zone, as evidenced most dramatically in the debt crises that has torn apart Greece and threatens to engulf a number of other southern European countries. In addition, democrats in Romania and Bulgaria have been discouraged by the persistence and in some respects resurgence of illiberal and 
corrupt political practices now that the "heat" of EU conditionality is long since off with the completion of the accession agreements. Yet, from the standpoint of democracy, these problems pale in comparison to the situation Europe faced on the eve of the third wave, when Greece was under a military dictatorship, Spain and Portugal were still ruled by long-term autocracies, and all of Central and Eastern Europe was behind the Iron Curtain of communist and ultimately Soviet domination.

The picture is bleaker in the 12 states of the former Soviet Union outside the Baltics. In most of these countries, including Russia, authoritarian rule seems firmly entrenched. Ukraine and Moldova are the only democracies, and since the pro-democracy forces imploded in the 2009 presidential election, Ukraine has been slipping back in terms of press freedom and the extent and health of democracy. Yet, since popular protests forced out the autocratic government in April 2010, Kyrgyzsgtan has moved back toward democracy. And political pluralism (if not quite democracy) remains alive in Georgia.

During the third wave, East Asia has gone from being the cradle and locus of "developmental authoritarianism," with Japan being the lone democracyand a longstanding one-party dominant system at that - to at least a mixed and progressing set of systems. Japan, Taiwan and Korea now all stand as liberal and consolidated democracies. They are hardly free of deep governance problems and serious citizen disenchantment, but that is true of the US many European democracies as well. Mongolia is also a fairly liberal democracy by the scores of Freedom House, and democracy also seems well established in Indonesia and (once again) the Philippines. But these countries, along with Thailand and East Timor, struggle with serious problems of rule of law, and Thailand suffers as well from crippling levels of political polarization.

Democratic pressures are clearly growing in Singapore and Malaysia as modernization proceeds (with Singapore being the richest non-democracy in per capita income in the history of the world). In May 2011, the long ruling party won its lowest percentage of the votes ( 60 percent) since becoming the dominant party from the start of Singapore's independence. In Malaysia, opposition political forces have made significant electoral inroads in recent years. The new opposition alliance, Pakatan Rakyat, is gaining momentum, and a transition to democracy could happen in Malaysia any time in the coming years, through the familiar instrument that has brought it in other competitive authoritarian regimes: the electoral process.

To be sure, authoritarianism is still well entrenched in six of the seventeen countries in Southeast Asia: China, Vietnam, Laos, Cambodia, Burma, and North Korea. But cracks are appearing in the edifice of many of these regimes 
as well, under the pressures of rapid modernization in China and of deepening development failure in North Korea.

Long a region of democratic vibrancy, South Asia has experienced considerable oscillation during the third wave, in part because of Pakistan's repeated democratic failures and now protracted descent into state decay as a result of extremist mobilization, military domination, and the incurable corruption and fecklessness of the civilian political parties and politicians. Another sad story has been the steady decay of Sri Lanka from a stable democracy to a highly illiberal one, ravaged by civil war, finally to a highly corrupt and abusive electoral autocracy. However, democracy remains sturdy and vibrant in India, and Bangladesh has once again returned to democracy after a brief interruption.

After Eastern Europe, the region that enjoyed the biggest democracy surge after the end of the Cold War was Sub-Saharan Africa. When the third wave began, there were only three democracies in Africa, and in very small countries: Botswana, Mauritius, and Gambia. Once the Cold War ended and African states were no longer pawns, to be wooed with aid and arms in a struggle between great powers, democracy flowered. By the middle of the first decade of this new century, about half of Africa's 48 states were democracies. No development in modern history so challenged the social science theory of structural pre-requisites for democracy, like economic development, widespread literacy, and a strong middle class. Moreover, by this point, many of the democracies in Africa, Asia and elsewhere were countries with Muslim majorities, like Turkey, Indonesia, Bangladesh, Mali, Senegal, and Niger.

The only region left untouched by this grand historical process of global democratization has been the Middle East - until this year. There were many Muslim-majority countries with significant democratic experience, but - except for Turkey — not in the Middle East. Until an outraged street vendor, Mohammed Bouazizi, fed up with years of petty predation and humiliation by the state, set himself aflame on December 17, 2010, thereby igniting the Tunisian revolution, the stirrings of democratic protest and limited reform in the region seemed to be leading nowhere. Now, there is at least a prospect of democratic change in a few Arab countries, and no Arab authoritarian regime feels as secure as it did in November 2010.

It is not difficult to draw additional hope and inspiration about the future of democracy in the world from these other facts:

- About three of every five states in the world are now at least electoral democracies.

- About two-thirds of the world's democracies (77) are reasonably highquality or "liberal" democracies, in the sense that electoral competition is institutionalized, fair, and open, civil liberties are better protected, 
and there are low levels of political violence and abuses or impunity by state security services.

- Democracy has become consolidated or at least endures in most of the important emerging market countries that have become members of the G20: India, Brazil, Mexico, Argentina, South Korea, Indonesia, Turkey and South Africa; only China and Saudi Arabia among this group are authoritarian.

- There is still no other type of political system in the world that represents anything approaching a rival model, despite the supposed growing attraction of China's authoritarian development "miracle".

- The United Nations and a variety of regional organizations have become more explicitly supportive of democracy as a universal value.

- Annual spending to promote democracy internationally has grown significantly beyond the early considerable efforts of first Germany (with its party foundations) and then the United States, with the UNDP and many bilateral aid programs of Europe, North America and Australia spending significant proportions of their overall budgets to monitor and support free and fair elections, assist democratic political parties and civil society organizations, fight corruption, enhance independent media, and strengthen the rule of law and other processes and institutions of "good governance."

- The Community of Democracies has gained considerable depth and momentum in the last few years, and will celebrate and consolidate its recent progress here in Ulan Bataar in April of next year.

\section{Five Years of Democratic Recession}

That is the largely good news, but unfortunately it is not the whole news. For the past five years at least, the world has experienced a marked democratic recession. This is indicated by several statistics. First, the number of democracies has been declining in the last several years. By my count, the number of electoral democracies has declined from a peak of 121 in 2006 to 116 in 2011 (though this does represent a slight increase from the previous year). Second, there has been a rising tide of breakdowns of democracy. Nearly a third of all the democracies that have existed during the third wave have broken down (with some countries like Thailand and Nigeria experiencing repeated breakdowns). And the pace of breakdowns has accelerated since the 1999 coup that toppled the civilian democracy in Pakistan. If we divide the 38 years of the third wave into three roughly equal periods of about a dozen years, we find that 16 percent of the existing democracies broke down between 1974 and 1985, less than 12 
percent between 1986 and 1998, but nearly 20 percent between 1999 and 2011. Moreover, of the 54 breakdowns or reversals of democracy that have occurred since the third wave began in 1974, roughly half of them have occurred since 1999. And 16 of these have taken place just in the past six years.

During the past six years, freedom levels have steadily declined. The years 2006 through 2010 have been the longest period of decline in freedom since the great burst of democratic expansion after the Cold War ended. In each of these years, more countries declined than improved in their Freedom House ratings of political rights and civil liberties, and the deterioration was particularly marked in the years 2007 through 2011, when in each year more than twice as many countries declined as improved in their freedom levels.

Of course, the declines in democracy and in freedom are related. First, obviously, when democracy is lost, freedom levels decline. But, particularly since 1990, democracy has generally broken down where it has been of lower quality. Generally, breakdowns have occurred in illiberal democracies, and often in extremely illiberal ones. The factors underlying low democratic qualitymost typically, extensive corruption, abuse of power, and a weak rule of law, often accompanied by significant levels of violence and violations of rightsare also the factors that incline democracies to breakdown. Weak and illiberal states provide a poor foundation for democracy. There is a significant correlation between the quality of democracy and the political stability, legitimacy, and progress toward consolidation of democracy.

There is another sobering aspect to the state of democracy in the world. A number of the countries that Freedom House classifies as electoral democracies Steven Levitsky and Lucan Way insist (in their recent book, Competitive Authoritarianism) should be removed from the list because elections are so unfair, or the political playing field is so uneven, or civil liberties are so constrained, that the system is really better understood as "competitive authoritarian." By a rigorous application of these more demanding standards for electoral democracy, the real number of democracies in the world might be little more than 100, closer to half of the states of the world.

Worries about the resilience of the third wave of democracy arise from less tangible or measurable factors as well. With China's continuing economic boom has come a rising prestige and growing projection of its economic power. There is growing fascination in some quarters with the "China model," which (it is argued) can cut through the tedious delays and coalitional demands of democratic politics and simply make economic decisions, budgetary allocations, and infrastructural investments based on what will yield the greatest and most rapid national gains in development. It is hard to argue with success, and neoCommunist China is. But China also struggles with some very big developmental 
problems and contradictions, and the bigger story that is starting to gain notice is the continuing shift in the locus of global economic growth and energy away from the advanced industrial democracies toward the emerging market economiesmostly democracies - like those that have recently joined the G20. For every emerging authoritarian developmental success story in the world today, there are more cases of authoritarian stagnation or democratic progress.

Two other negative trends cast a certain shadow over current global democratic prospects. One is the backlash against civil society and international democracy assistance that has been building for the past six to seven years. Particularly since the color revolutions, authoritarian regimes like those in Russia, Belarus, China, Iran and throughout Central Asia have taken careful note of the positive contribution that international democracy assistance (including grants to civil society organizations and election monitoring) have made to democratic advances and breakthroughs. Consequently, they have sought to frustrate, close off, and even criminalize these flows. Some African autocracies like Ethiopia and Sudan have eagerly jumped on the bandwagon of this backlash and appear to have (at least for now) consolidated or entrenched their authoritarian rule as a result.

\section{Why Democracies Have Failed During the Third Wave}

What has consistently plagued the failed and failing democracies of the third wave has been bad governance. What makes these democracies vulnerable is not poverty per se but several other conditions that are much harder to surmount at lower levels of economic development: rampant corruption, low state capacity and efficiency, weak rule of law, crime and insecurity, political and ethnic violence, and political polarization. It is not that middle-income (and even some upper-income countries) do not struggle with these problems, but the quality of governance simply tends to be poorer in lower-income countries, and this in itself makes democracy more vulnerable. And in addition, other dimensions of the quality of democracy, such as participation, civil society, and the fairness and transparency of elections themselves, also tend to be weaker in lower-income countries. Thus, this is where the disproportionate share of the democratic erosion has been during the third wave, and this is where the greatest challenge of deepening and consolidating democracy lies - though it should be noted that democracy has persisted for more than a decade or even two in a surprising number of lower-income countries in Africa and Asia.

Most of the democracies that have broken down in the past decade or so were in the bottom third of the distribution on most of the six World Bank indicators of the quality of governance around the time their democracy was overthrown or strangled by executive abuse. 
The troubled and failed democracies of recent times have shared a few key characteristics. First, they tend (with a few exceptions like Russia, Venezuela, and Thailand) to be poor or lower-middle-income, with per capita incomes (in purchasing power parity dollars) under $\$ 5,000$. Second, they are poorly governed. Not only do they have weak rule of law and rampant corruption, but their governments are not very effective in terms of the quality and independence of the civil service, and of public services and policy formulation and implementation more generally. Third, they are politically unstable, with significant levels of politically motivated violence. Fourth, they are deeply polarized on class, ethnic, or other lines of cleavage (sometimes, as in Bangladesh, deeply rooted in enmity between parties), which is one reason why they suffer civil wars and high levels of political violence. Fifth, executive power is seriously abused.

Executive abuse of power has been in the key factor in the demise of democracy in places like Russia, Venezuela, Nigeria, the Philippines, Georgia, Honduras, Niger, and Nicaragua, and it certainly played a role in others like Pakistan and Kenya. By contrast, "effective constraints on executive power substantially increase the chances that democracy will survive" in post-transition and fragile circumstances.

Interestingly, crises of imploding economic growth or spiraling unemployment have figured less prominently in the failure of democracy in the last two decades. Certainly, economic and social injustice forms the backdrop for the crises of social and political polarization that have been gathering in Latin America for quite some time. But the world's fragile democracies are mostly poor countries that are not well integrated into world markets. It is too early to dismiss the global economic downturn as a factor that could undermine the stability of democracies, but at most its effects seem likely to be secondary, reinforcing other negative trends.

\section{Grounds for Hope, Sources of Resilience}

While there are grounds for serious concern about the global state of democracy, there are also sound bases for judicious optimism. If there is restlessness with democracy in many places, there is generally greater unease if not disgust with authoritarian rule - as has been witnessed in a number of Arab countries in the past eighteen months. The Arab Spring protests have shown the underlying insecurity and fragility of the world's remaining authoritarian regimes. No less, they affirm that the desire to live in dignity, with freedom and political choice, is as nearly universal a political value as we have in our time. In fact, public opinion surveys show overwhelming proportions of Arabs preferring a democratic system. In other regions, majorities of the public in most countries continue to believe that democracy is the best form of government, or at least 
that all other known forms are worse. Even where (as in much of East Asia and Central and Eastern Europe) citizens have a low opinion of parties, politicians, and parliaments, they do not prefer to live under authoritarianism in general nor under any concrete authoritarian options that they can imagine.

For all of democracy's troubles in the past decade or so, there has still been no "reverse wave" of democratic breakdowns on anything like the scale of what ended the first and second waves of global democratization during the 1920s and 30s (preceding but accelerating with the Great Depression) and then again during the 1958-75 heyday of military coups and socialist or developmental autocracies. This is all the more remarkable given that the world has been living through the worst period of economic turmoil and downturn since the Great Depression. So far, third wave democracies have mainly responded to economic crisis and pain by replacing incumbent governments at the ballot box, rather than by replacing democratic regimes. Moreover, economic contraction does not seem to have been a significant cause of democratic breakdowns in the last decade or so. Generally, those democracies that were extinguished as a result of the mounting executive abuses of power were experiencing robust economic growth at the time. This was particularly true of the oil countries, but the same was true to a lesser extent of the Philippines and Kenya. In the case of the oil countries, it is even plausible that the booming oil economies added to the incentive to strangle democracy. To be sure, it is hard to locate the demise of democracy precisely in time when it is due to a gradual process of decay rather than a discrete event like a coup, but the pattern is striking.

The surprising story of many third wave countries has been the resilience of democratic politics in the face of sometimes severe economic downturns. I stress "politics" because it appears to be the normalization of electoral politics that spared these democracies the fate of many new and vulnerable democracies during the 1920s and 30s. In the past few years, stressed and unhappy voters have thrown out incumbents, not democracy itself. "In most cases where economic downturns were severe, with the growth rate in the election year plummeting by at lest seven percentage points (as happened in Bulgaria, Mexico, Mongolia, Panama, and Ukraine), incumbents took a beating." Where the downturn was less severe, incumbents had a much better chance of surviving (about 50 percent). "In general, democratic elections have performed as intended in times of economic distress, providing a safety valve that allows voters to punish incumbents while preserving the system as a whole." ${ }^{2}$

And it remains the case that above a certain upper-middle threshold of per capita income, roughly $\$ 10,000$ in 2009 Purchasing Power Parity (PPP) dollars, there is virtually no instance of a democracy breaking down. About 25 third-wave democracies (not just Taiwan, Korea, and the new EU entrants but Turkey, Brazil 
and South Africa as well) are now above that minimum threshold. In short, the universe of stable and consolidated or relatively secure democracies seems to have expanded significantly.

\section{The Future of Democracy}

With the economic and political woes of Europe, Japan, and the United States these days, there is beginning to emerge a new rhetoric of skepticism if not outright pessimism about the capacity of democratic institutions to solve the fundamental problems of aging populations and physical infrastructure, spiraling debt burdens, and declining economic competitiveness. The moment is not unlike the mid-1970s, when the Trilateral Commission produced its famous report on "The Crisis of Democracy" (the focus of which was heavily on "governability.") Wealth and power are shifting away from Europe and North America to the developing regions. Polls show that people in these regions want democracy not so much because it is the political formula of "the West", but because it provides basic political goods - political freedom, voice, accountability, popular sovereignty, and a rule of law-that authoritarian regimes cannot. So long as democracy can indeed provide these political goods, and reasonable progress in economic development as well, it will continue to be valued and embraced, even if its performance in the "West" continues to disappoint.

One flaw in the pessimistic line of analysis is the assumption that while Europe and the U.S. will thrash about in political frustration and economic decline, China will continue to boom, with the Communist Party in the driver's seat. This assumption is deeply flawed for two reasons. First, China is facing its own looming developmental challenges, in the form of an overheated real estate market, a potentially vulnerable banking sector, a looming severe labor shortage, and massive unaddressed environmental stresses. It is unlikely that China can continue for much longer the torrid pace of 8 to 10 percent economic growth that it has sustained for the past two decades. It is not yet clear how (or how well) the Communist Party will manage the frustrations of slowed growth, and the vulnerabilities cited above. In its current per capita GNP, China has already long since entered the famous "political zone of transition" that Samuel P. Huntington identified in his book, The Third Wave, as the likeliest developmental zone for democratic transitions. Within a decade or two at most, it will have the per capita GNP level that South Korea had in 1987. When China has as large a middle class, in proportional terms, as South Korea had in 1987 — and with increasing access to the Internet and social media-will its people continue to accept the unaccountable one-party hegemony of Communist rule? Through incremental political reform or through another eruption of mass protest from below, China is 
headed for a hge political transformation in the next generation. Democracy is not the inevitable outcome, but it will inevitably be widely demanded. In fact, there is a much greater prospect that China will become a democracy than that India, Brazil or South Korea will cease to be a democracy, much less that democracy in Europe or the United States will somehow fall apart.

The current moment is a difficult one for democracy. In the past five years, the momentum has clearly swung in favor of authoritarian retrenchment. That may continue for a few more years, or longer and deeper if the democracies lose their vision, commitment, and capacity to continue fostering and encouraging democracy globally. However, the long-term prospects for democracy remain encouraging. The mobilization of Arab societies for democratic change will not cease any time soon, and eventually some of them will get it. Even if some Arab countries enter the political cul-de-sac of Islamist authoritarianism, that regime form will eventually grow discredited the way it has in Iran. The inspiration for left populism in Latin America, the "Bolivarian" revolution in Venezuela, is collapsing. Indeed, the only thing that is sustaining authoritarian rule in Iran and Venezuela, and in Russia and much of the Middle East for that matter, is oil. Sooner or later, their contradictions will swallow them. For all their sluggishness and sleaziness, democracies retain one massive advantage over authoritarian regimes: The capacity for self-correction, and thus the flexibility to adapt rather than snap and break. Anyone who wants to wager on the comparative viability of regimes in the world would be wise to bet on democracy.

\section{End Notes}

1 Ethan Kapstein and Nathan ConverseThe Fate of Young Democracies (New York: Cambridge University Press, 2008), p. 68.

2 Larry Diamond, "The Impact of the Economic Crisis: Why Democracies Survive," Journal of Democracy 22 (January 2011), p. 27. Table 3 is also drawn from this article. 